\title{
Гербарні збори інтродуцентів, зроблені Й. К. Пачоським в Уманському Царициному саду (1885-1886 рр.)
}

\author{
Галина А. Чорна ${ }^{1}$, Тетяна В. Мамчур ${ }^{2}$

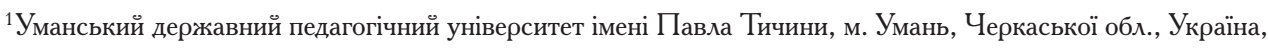 \\ e-mail: udpu_botanika@ukr.net \\ ORCID ID0000-0002-9633-1618 \\ ${ }^{2}$ Уманський наџіональний університет садівниџтва, м. Умань, Черкаської обл., Україна, e-mail: mamchur-tv@ukr.net \\ ORCID ID0000-0001-9320-814X
}

\section{Реферат.}

У статті наведено перелік невідомих на сьогодні ранніх гербарних зборів Й. Пачоського, знайдених у складі історичного гербарію УНУС (UM). За сучасною ботанічною номенклатурою (Plant List) џі збори включають 119 видів, 97 родів і 54 родини із відділів Pinophyta та Magnoliophyta. Гербарій зібрано Й. Пачоським у 18851886 рр. в оранжереях підпорядкованого Уманському училиџу землеробства та садівниџтва Џариџиного саду (Ex calolaris Umaniense) та розсаднику квітково-декоративних рослин училища (Ex horto botanico Umaniense). Проаналізовані нами гербарні збори та «Прейскурант рослин і насіння Уманського Џариџиного саду» (Prejskurant..., 1885) дозволяють констатувати, шо асортимент оранжерейних і тепличних рослин џього саду наприкінці XIX ст. нараховував близько 700 таксонів, квітниково-декоративних рослин незахищеного грунту - близько 200. Крім того, сад пропонував багатиї асортимент садивного матеріалу плодових і декоративних дерев і кушів. Гербарні зразки містять ранні автографи Й. Пачоського. Ним власноруч зазначено латинські назви виду та родини, в окремих випадках синоніми. Вказана також батьківшина оранжерейних рослин: Австралія (Нова Голландія), Пів-

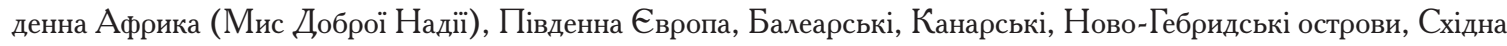
Індія, Китай, Японія, Бразилія, Мексика, Перу, Чилі, тобто в оранжереях досить широко була представлена флора тропічних (як палеотропіків, так і неотропіків) і субтропічних регіонів. Опраџьований гербарій вказує на інтерес Й. Пачоського не лише до видів природної флори, а і до інтродуџентів субтропічного та тропічного походження. Крім того, џей гербарій є документальним свідченням шодо складу колекџій Уманського Џариџиного саду в кінџі XIX ст.

Ключові слова: Й. К. Пачоський, гербарні збори, історичний гербарій Уманського наџіонального університету садівниџтва (UM), оранжереї Уманського Џариџиного саду.

\section{Herbarium Collection of Alien Plants Made by Yo. K. Pachoskyi in Uman Tsaritsyn Garden (1885-1886)}

\author{
Galina A. Chorna ${ }^{1}$, Tatiana V. Mamchur ${ }^{2}$ \\ ${ }^{1}$ Pavlo Tychyna Uman State Pedagogical University, Uman, Cherkasy region, Ukraine, e-mail: udpu_botanika@ukr.net \\ ORCID ID0000-0002-9633-1618 \\ ${ }^{2}$ Uman National University of Horticulture, Uman, Cherkasy region, Ukraine, e-mail: mamchur-tv@ukr.net \\ ORCID ID0000-0001-9320-814X
}

\section{Abstract.}

The article provides a list of unknown early herbarium yield of Yo. Pachoskyi, found as part of the historical herbarium of UNUH (UM). According to the modern Botanical nomenclature (The Plant List), that collection included 119 species, 97 genus and 54 families from Pinophyta and Magnoliophyta. The herbarium had been collected by Yo. Pachoskyi 
in 1885-1886 in conservatory subordinate to Uman School of Agriculture and Horticulture of the Tsaritsyn garden (Ex calolaris Umaniense) and nursery of ornamental plants of the school (Ex horto botanico Umaniense). Analyzed herbarium collection and «Price List of Plants and Seeds of Uman Tsaritsyn Garden» (Prejskurant..., 1885) allow us to state that the range of greenhouse and hothouse plants in the late $19^{\text {th }}$ century were about 700 taxa, flower-ornamental plants of nonprotected soil - about 200. In addition, the garden offered a wide range of fruit and ornamental trees and shrubs. Herbarium specimens contain the earliest autographs of Yo. Pachoskyi. He personally provided the Latin names of species and families, and in some cases synonyms. The homeland of greenhouse plants was also indicated: Australia (New Holland), South Africa (Cape of Good Hope), southern Europe, the Balearic, Canary, New Hebrides, Eastern India, China, Japan, Brazil, Mexico, Peru, Chile. The flora of tropical (both Paleotropics and Neotropics) and subtropical regions was widely represented in the greenhouse. The studied herbarium indicates the interest of Yo. Pachoskyi not only to a species of natural flora, but also to the alien plants of subtropical and tropical origin. In addition, this herbarium is a documentary evidence of the composition of Uman Tsaritsyn garden collections in the late $19^{\text {th }}$ century.

Key words: Yo. K. Pachoskyi, herbarium collections, historical herbarium of Uman National University of Horticulture (UM), greenhouses of Uman Tsaritsyn garden

Вступ/Introduction. Найбільш ранніми гербарними зборами Й. К. Пачоського на сьогодні вважалися збори дикорослих і найбільш поширених культивова-

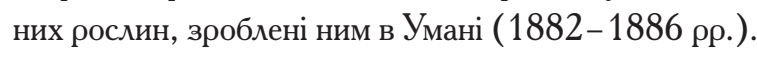
Џей гербарій послужив основою першої друкованої праці майбутнього вченого (Pachoskyj, 1887) та своєрідною перепусткою до членства у Київському товаристві дослідників природи.

Як стало відомо після опраџювання нами історичного гербарію УНУС (UM), у 1885-1886 рр. И. К. Пачоський гербаризував також у тепличнооранжерейному комплексі училища (Ex calolaris Umaniense) та розсаднику квітково-декоративних рослин (Ex horto botanico Umaniense) (Chorna et Mamchur, 2017). У складі «Основного гербарію училища» збереглося близько 130 гербарних зразків (г.з.) із автографами Й.К. Пачоського, невідомих раніше його зборів екзотичних інтродукованих видів.

Метою даної публікаџї є обнародування віднайденої колекџії, шо ілюструє не лише багатоплановість ботанічних зацікавлень Й. К. Пачоського вже у молоді роки, а також історію інтродукџї̈ рослин в Україні в останню чверть XIX ст.

Матеріали і методи/Materials and Methodology. Нами проаналізовано 127 г.з. із складу Історичного гербарію УНУС (UM), зібраних у 1885 1886 рр. в оранжереях Уманського «Цариџиного саду» (Ex calolaris Umaniense) та розсаднику квітково-декоративних рослин (Ex horto botanico Umaniense) та складено анотований перелік змонтованих на них видів рослин у відповідності до правил сучасної ботанічної номенклатури (Plant List). Інтродуџенти з відділу Pinophyta нами подаються загальним списком, без поділу на таксони незахищеного чи захищеного грунту, оскільки на гербарних етикетках Й. Пачоського помітка про місџезнаходження «Ex calolaris Umaniense» зустрічалася лише для окремих із них. Ідентифікаџія таксонів за каталогом рослин Ботанічного саду ім. акад. О. В. Фоміна (O. V. Fo$\min . . ., 2007)$ для окремих видів, наприклад Cryptomeria japonica (Thunb. ex L. f.) D. Don., вказує на те, що вони можуть культивуватися як у захищеному, так і незахищеному грунті. Метою даної публікаџї̈ насамперед було подати повний перелік г.з. Й. Пачоського, з ясування місџя культивування - завдання для дендрологів. Серед гербарних зборів голонасінних, ідентифікованих за написами на гербарних сорочках як збори Й. Пачоського, наявні види родів Cеphalotaxus (Cephalotaxaceae), Abies, Pinus (Pinaceae), Podocarpus (Podocarpaceae), Taxus (Taxaceae), Cryptomeria, Cunninghamia (Taxodiaceаe) без вказівки на рік і місџе збору. Оскільки це здебільшого різні за походженням інтродуџенти, ми також включаємо їх до џього переліку. Перелік покритонасінних складено окремо для видів, зібраних $($ Ex calolaris...) та (Ex horto...), за абеткою латинських назв таксонів: родин у межах відділів, родів у межах родин, видів у межах родів. Після назви виду вказані інвентарні номери, присвоєні г.з. в сучасному Гербарії УНУС (UM).

Наявність авторських гербарних етикеток із зазначенням прізвища колектора - Joseph Patczoski (рис. 1) на кількох гербарних зразках дозволила нам за автографом Й. Пачоського індентифікувати авторство тих зразків, де прізвише було відсутнє. Свого часу уманські збори учня училища садівниџтва Й. Пачоського були інсеровані до «Основного гербария Уманского училища земледелия и садоводства». 
Про џе свідчить наявність на них інвентарного номера г.з., прийнятого в џьому гербарії із вказівкою №№ роду, виду та загального порядкового номера. Для деяких зразків рукою колектора зазначено також, звідки походить рослина: Acacia armata R. Br. (Australia); A. melanoxylon R. Br. (Nova Hollandia); Buxus balearica Willd. (Insular Balearic) тошо. Більшість рослин визначено до виду, окремі, зокрема Nepentes sp., лише до роду. Всі рукописні помітки Й. Пачоського, в тому числі польською мовою, включено нами до переліку та взято в квадратні дужки. Якшо біля г.з. наявна етикетка, набрана типографським способом, то прізвище колектора виокремлене круглими.
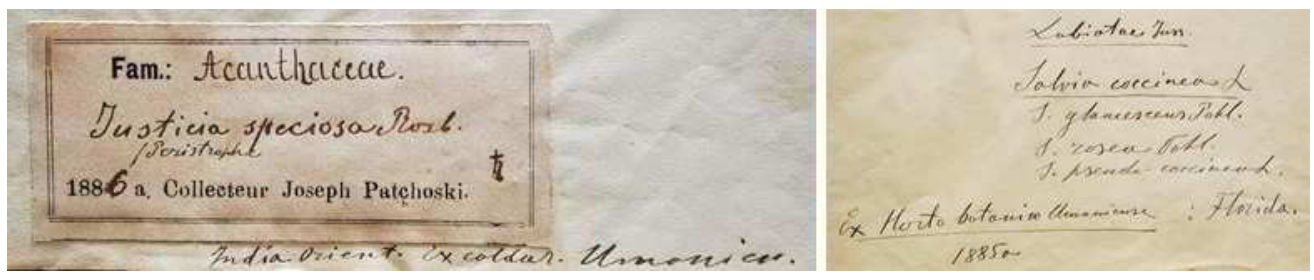

Рисунок 1. Гербарні етикетки уманських зборів Й. К. Пачоського

Figure 1. Herbal labels of Uman's collection by Yo. K. Pachoskyi

\section{Результати та обговорення/Results and Discus-} sion. За понад віковий період існування «Основного гербария Уманского училища земледелия и садоводства» в зв' язку з реорганізаџією навчального закладу та його кафедр і кабінетів, аварійним станом приміщень (не слід забувати, що колекџія пережила дві світові війни) сам порядок розташування гербарних зразків зазнавав неодноразових змін. До 1910 р. (Umanskoe..., 1910) џей гербарій використовувався учнями училища при вивченні систематики рослин. Із плином часу зростала історична џінність џих зборів, тому завідувач кафедрою ботаніки у 19791997 рр. В. А. Гаврилюк ретельно слідкував за їі збереженням. У навчальному проџесі вона вже не використовувалася.

Опраџювання колекџії було поновлене у 20132014 рр. Т. О. Кравеџь. Згодом, коли у 2014 р. куратором гербарію стала Т.В. Мамчур, до роботи з історичними колекџіями була залучена також Г. А. Чорна.

У 2013-2015 рр. було створено каталог колекторів гербарію, шо дозволило виділити в окремі одиниџі зберігання ряд раритетів, зокрема ексикати «Herbarium Florae Rossica», іменні збори М. Турчанінова, В. Черняєва. Й. Пачоського. Гербарні зразки останнього були розмішені на аркушах паперу формату 22,3×25,7 см із тисненням на папері в правому верхньому кутку «Дитятковское товарищество» виробниџтва Одеської паперової фабрики.

Оскільки дані гербарних етикеток або дані, шо для більшості гербарних зразків були вказані безпосередньо на гербарних сорочках, були неповні, ми намагалися знайти інші свідчення про місџе збору загербаризованих рослин. Запис «Ex calolar(is)» опосередковано вказував, що рослини могли бути зібрані в оранжереях Џариџиного саду. Підтвердженням џього завдячуємо «Прейскуранту рослин і насіння Уманського Џариџиного саду» (Prejskurant..., 1885).

Неодноразово увагу на роль старовинних парків, зокрема парку «Софіївка» $з$ його величною оранжереєю та теплиџями, як першоджерел інтродукџї тропічних і субтропічних рослин в Україні, звертала увагу Т. М. Черевченко (Cherevchenko, 2000, 2006). Вона наголошувала на тому, шо в XIX ст. асортимент екзотичних рослин парку «Софіївка» був надзвичайно різноманітним. Рослини в оранжереях i теплиџях були добре доглянуті, џвіли та плодоносили. Вдале розташування рослин в оранжереях, а влітку прикрашання екзотами у великих горщиках окремих ділянок парку посилювало декоративний ефект (Thermery, 1846). Близько 20 тис. горџикових рослин нараховувалось у оранжереях і теплиџях наприкінуі XIX ст., серед них відзначились своїми розмірами та екзотичною красою Cryptomeria japonica (Thunb. ex L. f.) D. Don, Magnolia grandiflora L., Casuarina equisetifolia Forst., тошо (Pashkevych, 1894).

За останніми даними сучасна колекџія тропічних і субтропічних рослин у новозбудованій оранжереї НДП «Софіївка» НАН України становить 223 таксони видового та внутрішньовидового рівня, 40 
культиварів і гібридів із 143 родів, 64 родин. Провідними за видовим складом нині є родини Aceraceae Juss., Asparagaceae Juss., Cactaceae Juss., Crassulaceae J. St.-Hil., Xanthorroeaceae Dumort., Commelinaceae Mirb. 3 метою відновлення історичного різноманіття тропічних і субтропічних рослин у захищеному грунті відбувається шорічне поповнення колекџії (Usol'tseva, Koval'chuk, 2015). У 2018 р. вперше після багаторічної перерви в теплиџях «Софіївки» знову заџвів південно-африканський Agapanthus umbellatus L. Відновлено висаджування у парк влітку Agave americana L.

Наявність документальних свідчень про видовий склад колекцій оранжерейних і тепличних рослин парку «Софіївка» в часи його становлення та розквіту сприятиме дотриманню вимог до відновлення історичних колекџіи.

\section{Перелік інтродуковних рослин відділу голонасінні}

\section{Pinophyta}

\section{Araucariaceae}

Araucaria columnaris (G. Forst.) Hook.

UM (2676). [Araucaria cookii R. Br. ex Endl. Новая Каледония. Ex calolariis Uman. 1885].

Araucaria bidwillii Hook.

UM (2675) [Nova Hollandia. Ex calolar Umanien. $1885 \mathrm{a}]$.

\section{Cephalotaxaceae \\ Cephalotaxus fortunei Hook. UM (2677)}

Pinaceae
Abies alba Mill.
UM (2809) [Coniferae. Abies pectinata Lam. et
DC.].

Abies cephalonica Loudon

UM (2810) [Abietineae Rich. Abies peloponensis Mill.].

Abies cilicica (Antoine \& Kotschy) Carrière UM (2807) [Coniferae. Abietineae Rich. Abies cilicica Carr Spach.

Abies nordmanniana (Steven) Spach UM (2808) [Coniferae. Abietineae Rich. Abies nordmanniana, Picea nordmanniana Stev., Pinus nordmanniana Stev. Кавказ].

Abies pinsapo Boiss UM (2811) [Coniferae. Abietineae Rich.]. Pinus pinaster Aiton
UM (2812) [Abietineae Rich. Pinus pinaster Solond.].

\section{Pinus radiata D. Don}

UM (2815) [Coniferae. Pinus tuberculata D. Don.

Калифорния. Америка].

Pinus sabiniana Douglas.

UM (2813) [Coniferae].

Pinus sabiniana Douglas.

UM (2814) [Abietineae Rich. Калифорния]. Podocarpaceae

Podocarpus elongatus (Aiton) L'Hér. ex Pers.

UM (2680) [Fam. Coniferae Subfom. Podocarpeae.

Podocarpus elongata L. Herif.].

\section{Taxaceae}

Taxus baccata L.

UM (2803) [Taxineae Rich. Krym-Europa i Azya].

Taxus baccata $\mathrm{L}$.

UM (2804) [Coniferae. Taxineae Rich. Taxus baccata $\mathrm{L}$. var T. dovastaniana hort].

Taxus baccata $\mathrm{L}$.

UM (2805) [Taxus baccata L. var $\beta$ hybernica, T. fastigiata Lindl.].

Taxus baccata $\mathbf{L}$.

UM (2806) [Coniferae. Taxineae Rich. Taxus fortigiata Lindl., T. hybernica Hook., T. piramidalis Hort., T. baccata L. var hyberica].

Taxus baccata $\mathrm{L}$.

UM (2679) [Fam. Coniferae. Taxineae Rich. Taxus parvifolia Wender. T. tardiva Sieb., T. adpressa Hort., T. brevifolia Hort., Cephalotaxus tardiva, adepressa, brevifolia Hort. Отеч. Япония].

Taxus cuspidata Siebold \& Zucc.

UM (2678) [Cephalotaxus umraculifera].

\section{Taxodiaceae}

Cryptomeria japonica (Thunb. ex L. f.) D. Don UM (2681) [Fam. Coniferae. Cupressineae Rich. Cryptomeria japonica Don., Cupressus japonica L., Taxodium japonirum Brongn. Отеч. Япония].

Cunninghamia lanceolata (Lamb.) Hook. UM (2682) [Fam. Coniferae Abietineae Rich. Cuninghamiaceae. Cunninghamia sinensis $\mathrm{B}$. Br., Pinus lanceolata Dest., Belis lanceolata Iweet., Araucaria lanceolata hort., Belis jaculifolia Ialsb. Отеч. Китай, Япония. 1886].

Перелік рослин, зібраних у теплично- оранжерейному комплексі училища (Ex calolaris Umaniense)

\section{Magnoliophyta}


$\underline{\text { Liliopsida }}$

\section{Arecaceae}

UM (2683) [Fam. Palmae. Daemonorops asperrimus L. B., Calamus niger Willd. Ex calolar Uman. Ява. 1886а].

Chamaerops humilis $\mathrm{L}$.

UM (2686) [Palmae. Potad. Europa. Potuocan. Afryka].

Dicranopygium atrovirens (H. Wendl.) Harling UM (2684) [Palmae. Carludovica atrovirens H. Wendl., C. plicata Kl. Ex calolar Umanien. 1886a].

Rhapis excelsa (Thunb.) Henry

UM (2685) [Rhapis flabeliformis L. Fam. Palmae. (Collecteur Joseph Patchoski). 1886a].

Washingtonia filifera (Linden ex André) H. Wendl. ex de Bary

UM (2687) [Palmeae. Pritchardia filamentosa Wendl. Острова Тихого океана; из Уманск. Теплиџ. 1886a].

Magnoliopsida

\section{Acanthaceae}

Cyrtanthera pohliona Nees abaenb. $\beta$ var. velutina. UM (2690) Justica carnea Hort., Justicia magnifica Hort. Ex calolar Uman. 1885a.

Eranthemum igneum Linden.

UM (2691) [Acanthaceae. Peru. Z cicplovci Humanskiele. 1884a].

Justicia lindaviana Leonard

UM (2692) [Fam. Acanthaceae. Justicia speciosa Boxb. Peristropha. 1886a]. (Collecteur Joseph Patchoski). India Oriet. Ex calolar Umanien].

Libonia floribunda K. Koch.

UM (2693) [Acanthaceae. Из Уманск. Теплиџ. Бразилия. 1885].

Peristrophe sp.

UM (2694) [Acanthaceae. Peristrophe salicifolia Hassk., Peristrophe salicifolia Miq. Ex calolar Uman. India Wschod.].

$$
\text { Apocynaceae }
$$

Catharanthus roseum (L.) G. Don

UM (2696) [Apocyneae. Ex calolar Umanien. 1885a].

\footnotetext{
Aralia palmata Hort.

\section{Araliaceae}

UM (2697) [Araliaceae. Gilbertia palmata DC., India orientalis. Ex calolar Humanien. 1886a].

Fatsia japonica (Thunb.) Dne. \& Planch.
}

UM (2698) [Araliaceae. Fatsia japonica Dne. et Pl. Aralia japonica Thunb., A. sieboldi hort. Япония].

Hedera colchica (K. Koch) K. Koch.

UM (2699) [Araliaceae. Hedera colchica Koch. Ex calolar Umanien. 1886a].

Hedera nervosa Hosb.

UM (2700) [Araliaceae. Ex calolar Umanien]. Aristolochiaceae

Aristolochia fimbriata Cham.

UM (2701) [Aristolochiaceae. Aristolochia bonplandi L. America australis. Ex calolar Human. 1885a].

Aristolochia sempervirens L.

UM (2702) [Aristolochiaceae. Ex calolar Uman. Graecia. 1886a].

\section{Asclepiadaceae}

Gomphocarpus fruticosus (L.) W. T. Aiton UM (2703) [Asclepiadaceae. Asclepias angustifolia Schweigg. Ex calolar Umanien. 1885a].

Hoya carnosa ( $\mathrm{L}$. f.) R. Br.

UM (2704) [Asclepiadaceae. (Collecteur Joseph Patchoski). Ex calolar Umanien. Asia Australia. 1885a].

\section{Stisseria bufonia (Jacq.) Kuntze}

UM (2705) [Asclepiadaceae. Stapelia bufonia Jacq. (Collecteur Joseph Patchoski). Ex calolar Umanien. $1885 \mathrm{a}$ ].

\section{Asteraceae}

Cineraria flatonifolia Schrank.

UM (2706) [Fam. Compositae Adans. (Collecteur Joseph Patchoski). 1886a].

Kleinia articulata (L. f.) Haw.

UM (2784) [Ex calolar. Uman. Мыс Добю. Надежды].

Pericallis hybrida (Regel) B. Nord.

UM (2707) [Fam. Compositae. Cineraria hybrida Willd. (Collecteur Joseph Patchoski). 1886a].

$$
\text { Balsaminaceae }
$$

Impatiens walleriana Hook. f.

UM (2708) [Balsamineae. Impatiens sultani. Ex calolar Uman. 1885a].

$$
\text { Begoniaceae }
$$

Begonia davisi Hook. f.

UM (2709)

Begonia dichotoma Jacq.

UM (2710) [Ex horto calolariis Umaniensis. America. 1886a].

Begonia dietrichiana Irmsch. 
UM (2712) [Begonia fischeri Otto ef Dietr, Pritulia fischeri Kl. Бразилия].

Begonia hydrocotylifolia Otto ex Hook.

UM (2711) [Gireondia hydrocotylifolia Kl. Ex calolariis Umanien. Mexica. 1886a].

Begonia maculata Raddi

UM (2713) [Fam. Begoniaceae. B. argyrostigma

Fisch., Gaerdtia maculata Kl. Brazylia].

Begonia manicata Ad. Brong.

UM (2714) [Begoniaceae. Ex calolariis Umanien Mexica. 1886a].

Begonia rex Putz.

UM (2715) [Begoniaceae. Begonia Rex-Putreys.

Ex calolar Umanien India orientalis. 1886a].

Begonia $\times$ ricinifolia A. Dietr.

UM (2716) [Begoniaceae. Begonia ricinifolia hort.

Ex calolariis Umanien. 1886a].

Berberidaceae

Berberis aquifolium Pursh

UM (2719) [Berberideae. Mahonia aquifolium

Nut., Berberis aquifolium Tor. et Gr. Ex calolar

Uman. America sertentr. 1886].

Berberis darwinii Hook.

UM (2717) [Berberideae. Ex calolar Umanien.

O. Ruuoe. 1886a].

Mahonia fortunei (Lindl.) Fedde

UM (2718) [Berberideae. Berberis fortunei hort.

Ex calolar Umanien. 1886a].

Bignoniaceae

Tecoma capensis (Thunb.) Lindl.

UM (2720) [Bignonia capensis, Tecoma capensis G. Don. Ex calolar Humanien. М. Добр. Надежды. 1885a].

\section{Buxaceae}

Buxus balearica Lam.

UM (2722) [Euphorbiaceae. Buxus balearica

Willd. Ex calolar Human. Insules Bolearis. 1886a].

Buxus balearica Lam.

UM (2723) [Euphorbiaceae. Buxus longifolia

Boiss. Ex calolariis Humanien. Syria. 1886a].

$$
\text { Euphorbiaceae }
$$

Croton spiralis Müll. Arg.

UM (2721) [Euphorbiaceae. Croton spirale Bulle, Codiaeum variegatum Hook, Codiaeum pictum, crispum Hook. Ex calolar Umanien. Wyspy ocean spikoinego. 1885a].

Phyllanthus epiphyllanthus L.
UM (2725) [Fam. Euphorbiaceae. Phyllanthus falcatus Sw., Ph. epiphyllanthus Múll., Xylophylla falcata Sw. Bot. Pug. Tab 373. Троп. Америка].

Fabaceae

\section{Acacia dealbata Link.}

UM (2728) [Mimoseae. R. Brown. Ex calolariis Umanien. In Nowa Hollandia].

\section{Acacia dealbata Link.}

UM (2729) [Mimoseae. R. Brown. Ex calolariis Umanien. In Nowa Hollandia].

Acacia melanoxylon R. Br.

UM (2730) [Mimoseae. R. Brown. In Nowa Hollandia].

Acacia microbotrya Benth.

UM (2731) [Mimoseae. R. Brown. Ex calolar Humanien. Australia occident. 1885a].

Acacia paradoxa DC.

UM (2727) [Mimoseae R. Brovn. Acacia armata

R. Br. Ex calolar Human. Australia. 1885a].

Adenocarpus foliolosus DC.

UM (2733) [Papilionaceae L. Phyllolobae loteae

DC., Adenocarpus foliolosus DC.]

Havardia albicans (Kunth) Britton \& Rose

UM (2726) [Mimoseae R. Brovn. Acacia albicans

Kunth. H. B. Ex calolar Human. 1885a].

Mimosa pudica L.

UM (2732) [Mimoseae. R. Brown. Eumimosa

DC. Ex calolar Umanien. In Brasilia. 1885a].

Quercus ilex L.

$$
\text { Fagaceae }
$$

UM (2334) [Fam. Cupulifereae. (Collecteur Joseph Patchoski). 1885a].

\section{Lamiaceae}

Rosmarinus officinalis $\mathrm{L}$.

UM (2735) [Labiatae Juss. Ex calolar Umanien. Auropa australis, Asia. 1886a].

Salvia patens Cav.

UM (2737) [Labiatae. Ex calolariis Umanien Мексика. 1885a].

Malvaceae
Pavonia spinifex (L.) Cav.
UM (2739) [Malvaceae. Ex calolar Human. Amer-
ica meridionalis. 1885a].
Maranthaceae
Maranta eximia Regel.
UM (2740) [Marantaceae. Ex calolar Uman.
1885].

Mesembryanthaceae

Conophytum minutum (Haw.) N.E. Br. 
UM (2741) [Mesembryanthaceae. Mesembryantheum minutum Haw. Ex calolar Uman M. Доб Надеж. 1885a].

\section{Moraceae}

\section{Ficus sp.}

UM (2743) [Moreae. Ficus aunei L. Van-Houtte. Ex calolar Uman. 1885a].

Ficus nervosa subsp. pubinervis (Blume) C. C. Berg UM (2746) [Moreae. Ficus similis Rgl. (Urostigma), Ficus amazonica hort. Ex calolar Uman. Brasilia. 1886a].

Ficus pumila L.

UM (2744) [Moreae. Ex calolar Uman. 1885a].

Ficus saussureana DC.

UM (2742) [Moreae. Ficus affelii S. Don. Ex calolar Uman. India oriental. 1885a].

Ficus scabra G. Forst.

UM (2745) [Moreae. Ficus scabra Torsk. Из Уманск. Теплиџ. Нов. Габридские о-ва. 1886а].

\section{Myrtaceae}

Calistemon lancelatum (Sm.) Sweet.

UM (2747) [Myrtaceae. Calistemon lancelatum

DC. Ex calolar Uman. Australia. 1886].

Eucalyptus globulus Labill.

UM (2748) [Fam. Myrtaceae. (Collecteur Joseph Patchoski). Australia. 1886a].

Leptospermum myrtifolium Sieber ex DC.

UM (2750) [Myrtaceae. Leptospermum myrtifolium Salisb. Ex calolar Human. Australia. 1885a].

Melaleuca sp.

UM (2751) [Melaleuca alba hort. Melal. evicaefolia Smith. Ex calolar Human. Australia. 1885a].

Syzygium australe (J. C. Wendl. ex Link) B. Hyland UM (2749) [Fam. Myrtaceae Jambosa australis DC., Eugenia myrtifolia Sims., Eugenia australis Wendl., Myrtus australis L. Ex calolar Human. Нов. Голландія. 1885a].

\section{Nepenthaceae}

Nepenthes sp.

UM (2752) [Nepentheae. Ex calolar Human. 1885a].

\section{Oleaceae}

Jasminum nudiflorum Lindl.

UM (2753) [Jasmineae. Ex calolar Humanien.

Chiny. 1885a].

Phillyrea latifolia L.

UM (2754) [Oleaceae. Phillyrea media Lnk. Ex calolar Uman. Europa australis. 1886].
Rosaceae
Kerria japonica (L.) DC.
UM (2755) [Tiliaceae. Corchorus japonicus Thunb. Kerria japonica DC. Ex calolar Uman. Japonia. 1886a].

Sparmannia africana L. f.

UM (2756) [Fam. Tiliaceae. (Collecteur Joseph Patchoski). 1886a].

\section{Rubiaceae}

\section{Gardenia citriodora Hook.}

UM (2757) [Fam. Rubiaceae. (Collecteur Joseph Patchoski). 1886a].

Gardenia thunbergia Thunb.

UM (2758) [Из Уманской Теплиџы. Мыс Доброй Надежды. 1886].

\section{Ruscaceae}

\section{Ruscus androgynus $\mathrm{L}$.}

UM (2688) [Asparagineae. Insul Canariens. Ex calolariis Umaniensis. 1886a].

\section{Rutaceae}

\section{Citrus medica $\mathrm{L}$.}

UM (2759) [Fam. Aurantiaceae. Cytryna. Ex calolar Umanien. 1885a].

\section{Torenia asiatica $\mathbf{L}$.}

\section{Scrophulariaceae}

UM (2761) [Scrophularineae. Ex calolar Uman. Azya. 1885a].

\section{Solanaceae}

\section{Cestrum laurifolium L'Her.} UM (2762) [Solaneae. C. venenatum Lamh. Ex calolar Human. Auerique meridionale. 1885a].

Cestrum parqui (Lam.) L'Her.

UM (2763) [Solaneae Bchb. Cestrum parquidin. Ex calolar Human. Jagody crasne. Chili. 1885a].

Habrothamnus aurantiacus Regel.

UM (2764) [Solaneae. Cestrum regeli Planch. Ex calolar Uman. 1885a].

Smilax aspera L.

$$
\text { Smilacaceae }
$$

UM (2689) [Asparagineae. Smilax sagittifolia Lodd. Chiny. Humanskici lichlarni. 1886a].

\section{Verbenaceae}

Clerodendrum thompsoniae Balf. f. UM (2765) [Clerodendrum Thompsoni Boltor. Ex calolar Uman. America meridialis. 1883a].

Lantana nivea Vent.

UM (2766) [Ex calolar Uman. Brasilia. 1885a]. 
Перелік рослин, зібраних у розсаднику квітково-декоративних рослин училища (Ex hordo botanico Umaniense).

\section{Magnoliophyta}

\section{Apocynaceae}

Apocynum androsaemifolium $\mathrm{L}$.

UM (2695) [Apocyneae. Ex horh. Botan. Uman America septentsionolis. 1885a].

\section{Asteraceae}

\section{Ammobium alatum R. Br.}

UM (2781) [Compositae Adans. Senecionideae. Ex horto botanico Umanien. Nova Hollandia. 1884a].

Emilia sonchifolia (L.) DC. ex DC.

UM (2782) [Compositae Adans. Senecionideae. Cacalia sonchifolia L. Ex horto botanico Umanien. 1885a].

Lasthenia californica DC. ex Lindl.

UM (2785) [Compositae Adans. Ex horto botanico Umaniense. 1885a].

Senecio elegans $\mathrm{L}$.

UM (2786) [Compositae Adans. Ex horto botanico Uman. India. 1884].

\section{Buxaceae}

Buxus sempervirens $\mathrm{L}$.

UM (2724) [Euphorbiaceae. Ex horto Umanien. Europa australis. 1886a].

\section{Capparaceae}

\section{Cleome sp.}

UM (2787) [Capparideae. Ex horto botan. Uman. $1884 \mathrm{a}$ ].

\section{Caryophyllaceae}

Gypsophila elegans M. Bieb.

UM (2788) [Caryophylleae. Ex horto botanico Umanien. 1884a].

\section{Hydrophyllaceae}

Phacelia tanacetifolia Benth.

UM (2790) [Hydrophylleae. Ex horto botan. Uman. California].

\section{Lamiaceae}

Nepeta sp.

UM (2791) [Labiatae Juss. Nepeta bohomiane L. Ex horto botanico Umaniense. 1884a].

Salvia coccinea Buc'hoz ex Etl.

UM (2736) [Labiatae Juss. S. glauceus Pohl., S. rosea Vohl., S. pseudo-coccinea L. Ex horto botanico Umaniense. Florida. 1885a].

Satureja montana L.
UM (2792) [Labiatae Juss. Ex horto botanico Umaniense. 1885a].

Linaceae

Linum grandiflorum Desf.

UM (2793) [Lineae DC. Ex horto botanico Humanien. Algeria. 1885a].

\section{Lobeliaceae}

\section{Lobelia erinus $\mathrm{L}$.}

UM (2794) [Ex horto botanico Humanien. Отеч.

Мыс Добр. Над. 1885a].

\section{Lythraceae}

Cuphea miniata Brongn.

UM (2738) [Lythrorieae. Ex horto botanico $\mathrm{Hu}$ maniensi. Meksyka. 1885a].

\section{Onagraceae}

Oenothera sp.

UM (2990) [Onagrariae Juss. Oenothera biennis L. Энотера двудомная. Умань (Киев. губ.)].

\section{Oxalidaceae}

\section{Oxalis sp.}

UM (2795) [Oxalideae. Oxalis raldiviensis Barn.

Ex horto botan Uman. 1885a].

Papaveraceae

Lamprocapnos spectabilis (L.) Fukuhara

UM (2789) [Fumariaceae. Diclytra spectabilis DC.

Ex horto botanico Umanien. Chiny].

Macleaya cordata (Willd.) R. Br.

UM (2796) [Papaveraceae DC. Bocconia cordata Willd. Ex horto botan Uman. Chiny. 1884a].

Papaver alpinum L.

UM (2797) [Papaveraceae DC. Ex horto botanico Umaniense. 1885a].

Zea sp.

\section{Poaceae}

UM (2780) [Gramineae Juss. Zea stricta L. Ex horto botanico Uman. 1885a].

\section{Ranunculaceae}

Aquilegia chrysantha A. Gray.

UM (2798) [Ex horto botan Uman. Septern occident. America. 1885a].

Digitalis ferruginea L.

UM (2799) [Scrophularineae. Ex horto botanico Umaniense].

Mimulus guttatus DC.

UM (2800) [Scrophularineae. Mimulus (Telingi).

Ex horto botanico Umaniensis].

\section{Urticaceae}

\section{Urtica pilulifera $\mathrm{L}$.}


UM (2801) [Ex horto botan. Uman]. Verbenaceae

Verbena hybtida Groenl. \& Rumpler

UM (2802) [Hybr. hort. Ex horto bot. Uman. 1885a].

В Україні іменні гербарії Й. К. Пачоського наявні в Херсоні (KHEM*), Одесі (MSUD), його ранні уманські гербарні збори ввійшли до складу іменного гербарію I. Ф. Шмальгаузена (KW). Окремі гербарні зразки, зібрані Й. К. Пачоським, зберігаються також в ряді інших гербаріїв Києва (KWU*, KWHU), Львова (LW, LWS), Миколаєва $\left(\mathrm{MKM}^{*}\right)$, Сімферополя (SIMF) (Herbaria..., 2011). Проведена нами робота дозволяє доповнити цей перелік гербарієм УНУС (UM).

Життевий і творчий шлях видатного вченого охарактеризовано в цілому ряді статей, монографій (Latowski, 2012; Melnik, 2014). Однак, роки становлення особистості майбутнього вченого, зокрема уманський період, все ше лишаються мало відомими. Виявлені в складі історичного гербарію УНУС гербарні збори Й. Пачоського, зроблені в 1885 та
1886 в Уманському Џариџиному саду, дозволяють стверджувати, џо вже двадџятирічним юнаком він мав багатогранні наукові інтереси.

Висновки/Conclusions. Нами вперше зазначено, що до найбімьш ранніх гербарних зборів Й. Пачоського, крім видів природної та культивованої флори околиџь м. Умані Київської губ., належать 16 видів голонасінних інтродуџентів та покритонасінних екзотів (80 видів) зібраних в оранжереях і теплиџях Уманського Џариџиного саду. Крім того, 26 видів зібрано в колекџійному розсаднику декоративних рослин џього саду.

Виявлення у складі історичного гербарію УНУС (UM) зборів Й. Пачоського, їх опраџювання та виділення в окрему колекцію дозволяє доповнити відомості џодо наявності џінних колекцій в Україні.

Подяки/Acknowledgement. Автори висловлюють ширу подяку провідному бібліотекарю музейної кімнати стародруків Наукової бібліотеки Уманського нашіонального університету садівниџтва Наталії Василівні Михайловій і завідувачу музею історії університету Оксані Вікентіївні Свистун за допомогу у пошуку необхідної літератури та рукописних документів.

\section{Список посилань/References}

Cherevchenko, T. M. (2006). The Background of tropical and subtropical plants antroduction in Ukraine. Starodavni parky i botanichni sady - naukovi tsentry zberezhennia bioriznomanittia ta okhorona istoryko-kul'turnoi spadschyny: materialy mizhnarodnoi naukovoi konferentsii, prysviachenoi 210-richchiu Sofivky (m. Uman', 25-28 veresnia 2006 r.). [Red. I. S. Kosenko ta in.]. Kyiv: Akademperiodyka. S. 24-29. (in Ukrainian).

Cherevchenko, T. M., Chuvikina, N. V. (2000). Old parks as primary sources of introduction of tropical and subtropical plants in Ukraine. Plant introduction. № 2. P. 3-10. (in Ukrainian).

Chorna, H. A., Mamchur, T.V. Nevidomi herbarni zbory J. K. Pachos'koho. Materialy XIV z' izdu Ukrains'koho botanichnoho tovarystva (m. Kyiv, 25-26 kvitnia 2017 r.). S. 222. [Elektronnyj resurs]. Rezhym dostupu: http://www. botany. kiev. ua/doc/14_congress_UBT. pdf (in Ukrainian).

Herbaria of Ukraine. Index Herbariorum Ucrainicum. (2011). Editor: Natalia M. Shiyan. Kyiv. 442 p. (in Ukrainian).

Latowski, K. (2012). Z kart drogi życiowej Profesora Jósefa Paczoskiego. Jósefa Paczoski. Rozważania o świecie powiazań w świecie roślin. Poznań: PTP. 354 s. (in Polish).

Melnik, V. I. (2014). Jozef K. Paczoski (150th Anniversary). Ukrainian botanical journal. Vol. 71. № 6. P. 740-746. (in Ukrainian).

O. V. Fomin Botanical Garden. Index Plantarum (2007). Naturale reserve territories of Ukraine. Plant world. Iss.7. Kyiv: Phytosociocentre. 320 p. (in Ukrainian).

Pachoskyj, J. Ocherky flory okrestnostej h. Umany Kyevskoj hubernyy. Zapysky Kyevskoho obschestva estestvoyspytatelej. Kyev, 1887. T. VIII, Vyp. 2. S. 371-439. (in Russian).

Pashkevych, V. V. (1894). Umanskyj Tsarytsyn sad. Vestnyk Ymperatorskoho rossyjskoho obschestva sadovodstva. № 3. S. 107-179. (in Russian).

Prejskurant rastenyiam y semenam, prodaiuschymsia v Umanskom Tsarytsynom Sadu. Uman', Kyevskoj hubernyy (1885). S.-Peterburh: Typohrafyia V. Kyrshbauma. S. 19-79. (in Russian).

The Plant List. A working list of all planst species. [Elektronnyj resurs]. Rezhym dostupu: 
http:/ / www. theplantlist. org/

Thermery, T. (1846). Guide de Sophiowka, surnomme la merveille de L'Ukraine. Odessa. 150 s. (in French).

Umanskoe uchylysche sadovodstva y zemledelyia. Sostavleno dyrektorom uchylyscha M. E. Sofronovym pry uchastyy prepodavatelej y zaveduiuschykh otdel'nymy otrasliamy (1910). Sankt-Peterburh. S. 37. (in Russian).

Usol'tseva, O. H., Koval'chuk, T. D. (2015). Kolektsiia tropichnykh i subtropichnykh roslyn Natsional'noho dendrolohichnoho parku «Sofiveka» NAN Ukrainy: materialy mizhnarodnoi naukovoi konferentsii, prysviachenoi 60-richchiu Natsional'noho dendrolohichnoho parku «Sofivka», iak naukovoi ustanovy NAN Ukrainy (m. Uman', 6-8 zhovtnia 2015 r.). Red. I. S. Korenko ta in. Uman': «Vydavets' Sochyns'kyj». S. 153-154. (in Ukrainian).

\section{Національний дендрологічний парк «Софіївка» НАН України у 2018 році National dendrological park «Sofiyivka» of NAS of Ukraine (2018 brief review)}

Наџіональний дендрологічний парк «Софіївка»видатний пам'ятник садово-паркового мистеџтва світового значення кінџя XVIII - початку XIX століть, пам'ятка паркобудування й архітектури України, занесений до державного реєстру національного культурного надбання (схваленого рішенням Колегії Держкоммістобудування України 23.12.93 р. № 12 на підставі Постанови Кабінету Міністрів України від 12.08 .92 р. № 466), музей природи і садово-паркового мистеџтва. Колекџії рослин Наџіонального дендрологічного парку «Софіївка» розпорядженням Кабінету Міністрів України від 11.02.2004 № 73 внесені до реєстру Наџіонального надбання. Згідно з указом Президента України від 28.02.2004 № 249/2004 «Про надання дендрологічному парку «Софіївка» $\mathrm{HAH}$ України статусу нашіонального» парк іменується Наџіональний дендрологічний парк «Софіївка» Наџіональної академії наук України.

Наџіональний дендропарк «Софіївка» входить до складу Відділення загальної біології НАН України.

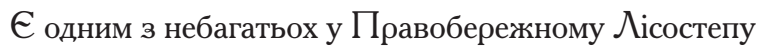
України центром мобілізації та акліматизації рослинного різноманіття, навчально-виховною базою для студентів вузів, учнів спеціальних навчальних закладів і загальноосвітніх шкіл, а також провідною установою в галузі садово-паркового будівниџтва та туристичною установою.
Основні напрями діяльності дендропарку:

- дослідження, моніторинг, збереження та охорона рослинного світу Лісостепової зони України;

- інтродукція, акліматизація, біотехнологія, селекџія

та репродуктивна біологія рослин;

- садово-паркове та ландшафтне будівниџтво.

Співробітники дендропарку вивчають, аналізують та узагальнюють досягнення дендрології та садовопаркового мистеџтва, визначають можливості їх використання в умовах дендропарку та інших парках України.

Структурними підрозділами дендропарку є наукові відділи:

1. Дендрології та паркобудівниџтва (з лабораторією ландшафтного дизайну та проектування, насіннєвою лабораторією та підрозділом дендрологів); 2. Генетики, селекџії та репродуктивної біології рослин (з лабораторією захисту рослин, лабораторією мікроклонального розмноження рослин та дослідновиробничим розсадником);

3. Трав'янистих рослин (з науковим гербарієм і підрозділом квітникарів).

У 2018 роџі співробітники Наџіонального дендрологічного парку «Софіївка» НАН України праџювали над виконанням чотирьох науково-дослідних тем (три з яких є фундаментальними, одна - прикладна). У проџесі ї виконання отримано наступні найвагоміші результати: 